\title{
POSSIBILITY OF OPERATIVE TREATMENT OF UTERINE SARCOMA: CASE REPORT
}

Radenko Ivanovic ${ }^{1}$, Helena Maric ${ }^{1}$, Vladimir Cancar ${ }^{1}$, Dragana Nikolic ${ }^{2}$, Radislavka Lecic ${ }^{1}$ and Milan Arsenovic ${ }^{3}$ ${ }^{1}$ University hospital Foca, Republic of Srpska, Bosnia and Hercegovina

${ }^{2}$ Medical Faculty of Foca, University of East Sarajevo, Republic of Srpska, Bosnia and Hercegovina

${ }^{3}$ Health Center Bijeljina, Republic of Srpska, Bosnia and Hercegovina

\author{
MOGUĆNOST OPERATIVNOG LEČENJA SARIKOMA UTERUSA: \\ PRIKAZ SLUČAJA \\ Radenko Ivanović ${ }^{1}$, Helena Marić ${ }^{1}$, Vladimir Čančar ${ }^{1}$, Dragana Nikolić ${ }^{2}$, Radislavka Lečići i Milan Arsenović ${ }^{3}$ \\ ${ }^{1}$ Univerzitetska bolnica Foča, Republika Srpska, Bosna i Hercegovina \\ ${ }^{2}$ Medicinski fakultet Foča, Univerzitet u Istočnom Sarajevu, Republika Srpska, Bosna i Hercegovina \\ ${ }^{3}$ Dom zdravlja Bijeljina, Republika Srpska, Bosna i Hercegovina
}

\begin{abstract}
Uterine sarcomas make up only 5\% of all malignancies in gynecology. Their classification is complicated due to low incidence and large histological differences. Uterine sarcoma is usually diagnosed in postmenopausal women, and this is most often done accidentally at the postoperative stage. The existence of uterine sarcoma should be suspected in cases of rapid uterine growth in postmenopausal state. Postmenopausal abnormal bleeding is the most common reason for a medical examination.

In this paper, a 48-year-old patient is presented in whose case during a regular gynecological examination; the existence of tumour change in the uterine part of uterus has been noticed. The patient did not have gynecological problems until then. The patient was then subjected to a diagnostic exploratory curettage. The pathohistological finding was negative. Given that the onset change is present after the control check, it is decided to proceed with an operative procedure. A pathohistological finding (uterus and adnexa) indicates that it is a uterine sarcoma. After that, the patient was re-treated with two more operations and then had chemotherapy and radiation therapy. After completing the whole treatment, for the period of six years, the patient now feels well and performs her usual work tasks.
\end{abstract}

Keywords: uterine sarcoma, operative treatment, chemotherapy

\section{SAŽETAK}

Sarkomi uterusa obuhvataju samo 5\% od svih maligniteta u ginekologiji. Njihova klasifikacija je komplikovana zbog male učestalosti $i$ velikih histoloških različitosti. Sarkoma uterusa se obično dijagnostikuje kod postmenopauzalnih žena $i$ to najčešće slučajno postoperativno. Na postojanje sarcoma uterusa treba posumljati u slučajevima rapidnog rasta uterusa u postmenopauzi. Postmenopauzalno abnormalno krvarenje je najčešći razlog za medicinski pregled.

U ovom radu prikazan je slučaj bolesnice, starosti 48 godina kod koje se na redovnom ginekološkom pregledu uoči postojanje tumorske promjene u istmičnom dijelu uterusa. Pacijentkinja nije imala ginekološke tegobe do tada. Pacijentkinja je potom bila podvrgnuta dijagnostičkoj eksplorativnoj kiretaži . Patohistološki nalaz je bio uredan. S obzirom da se uočna promjena I na kontrolnom pregledu održava odluči se uraditi operativni zahvat. Patohistološki nalaz ( uterus I adnexa) pokazuje da se radi o sarkomu uterusa. Nakon toga pacijentkinja u dva navrata bila podvrgnuta ponovnim operativnim zahvatima a potom hemio I zračnoj terapiji. Nakon sporovedenog kompletnog liječenja pacijentkinja se sada, sest godina, nakon okončanog liječenja osjeća dobro I obavlja uobičajne radne zadatke.

Ključne riječi: sarkom uterusa, operativno liječenje, hemioterapija
Corresponding author: Radenko Ivanovic University hospital Foca, University hospital Foca,
Republic of Srpska, Bosnia and Hercegovina e-mail: radenko84@yahoo.com 


\section{INTRODUCTION}

Adenosarcomas of the uterus are generally neoplasms of low grade, and are capable of recidivism after polypectomy or hysterectomy and are only very rarely metastatic. The two most important negative prognostic factors, which are occasionally present, are deep myometrical invasion with a predominant sarcomatous component and high morphological grade, which is followed by the loss of hormone receptors and CD10. Adenosarcoma can be mistaken for various lesions, and the main differential diagnosis is adenofibroma, which by definition has a morphologically benign component (3). The main symptom of these lesions is abnormal vaginal bleeding, pain in the lower abdomen, a palpable tumour mass in the lower abdomen, unusual urinary symptoms, increased and prolonged vaginal discharge, and sometimes the presence of polypoid tissue that can be seen in a dilated cervical canal (4).

These tumours have a tendency to appear in postmenopausal patients with an average age of 66 years. The average time interval from the first symptoms to the final diagnosis is approximately 13 months. The risk factors are similar to those of uterine adenosarcoma and include obesity, oestrogen therapy, radiation exposure, nulliparity, and potentially tamoxifen exposure (5). The prognosis is much better in the early phase and in younger patients, although these are often incorrectly treated due to an incorrect diagnosis (6).

\section{CASE REPORT}

Patient S.R. age 48, attends a regular gynecological examination in 2008 (until then regular gynecological examinations were negative). An ultrasound and gynecological examination in the area of the isthmus (lower part of the uterus) detect a tumour change (myoma). Doppler index in the region of tumour changes shows reduced resistance to flow through blood vessels $(\mathrm{Ri}<0.42)$. On $1 / 8 / 2008$ in the Gynecology Department of Hospital in Foca, exploratory curettage was performed. Pathohistological diagnosis: endometrium pieces, smooth muscle tissue pieces without atypical elements. On the control examination, in 3 months, a further increase in the described tumour changes was observed. During gynecological examination in the area of tumour changes, softening of the uterine wall in relation to the remainder of the uterus was noticed. On 25/11/2008, an operation was performed (Hysterectomia totalis abdominal cum adnexectomia bill) PHD (1674/08): Leiomyosarcoma uteri. Control checks 3, 6 and 9 months after surgery indicate a negative post-operative report. Control examination 15/12/2009 (EHO and NMR): Urinary bladder without pathological contents. Along the left wall of the bladder, a tumour with dimensions of $48 \times 46 \mathrm{~mm}$, in structure similar to myometrium with signs of central tumour necrosis with very rich vascularization. By decision of the Consilium for skin and soft tissue at the Institute of Oncology

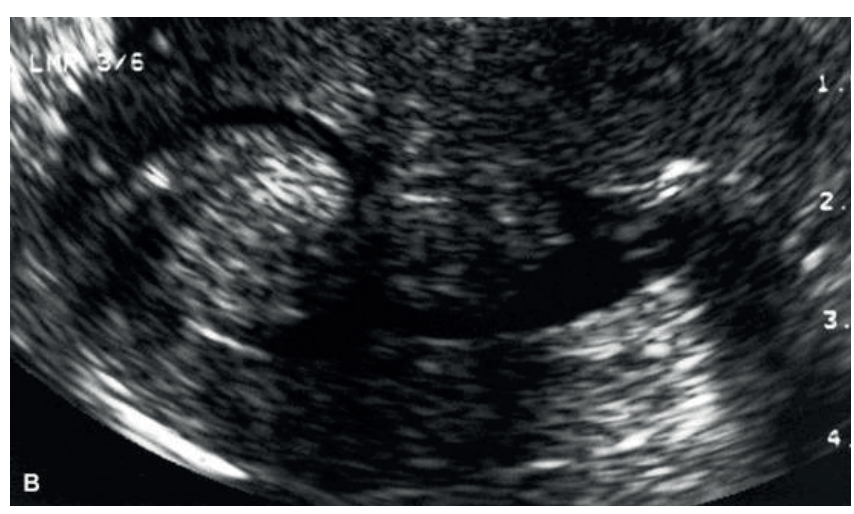

Picture 1. Tumor changes in the lower part (isthmus) of the uterus

and Radiology of Serbia (17.12.2009), on April 4, 2010, an operation was performed at the Clinic for Gynecology and Obstetrics of the Clinical Centre of Serbia (KGA KCS) Extirpatio tumoris in toto. Omentectomia partialis. Pathohistological diagnosis 222/10: Leiomyosarcoma (high degree of malignancy).

Examinations 3 and 6 months after surgery indicate a negative finding (PET / CT and MRI abdomen and pelvis) Control examination on 25.11.2010 (PET / CT Institute of Oncology of Vojvodina: Two focuses of intense gathering FDG localised at right side in the obturator foramen (above the urinary bladder) and to the left next to the anterior abdominal wall in the projection of the external iliac lymph nodes, differential diagnosis. They correspond to metabolically active secondary deposits.

On 27.12.2016, the patient was operated at the East Sarajevo Clinical Center, Foca hospital (Extirpatio tumoris in toto. Adhesiolysiss) Histopathology diagnosis: 2021-2022 / 10: metastaticum leiomyosarcoma, grade 2, total score 4 metastaticum et leiomyosarcoma, grade 2, the total score 4 .

Council For the pelvic surgery of the Clinical Center of Serbia and the Oncology Council of the Clinical Center Eastern Sarajevo made a decision on 09.02.2011 that the patient is to be administered by systemic chemotherapy protocol MAI 3 cycles, followed by radiation treatment and by an additional 3 cycles of chemotherapy after MAI protocol (ADM-CDDP).

After therapy completion, according to the decision by the oncology console, the patient is to attend regular examinations. A local finding in a small pectoris was negative. NMR and PET/CT examination came negative. MRI of the abdomen and pelvis on 07/10/2015 indicate: "...In addition to the findings of hemangioma of the liver and kidney cysts other findings in the abdomen and pelvic are negative. Finding PET / CT 10/10/2016..." On the obtained PET sections, zone of pathological accumulation of FDG, which would indicate the presence of a malignant tumour is not visible."

\section{DISCUSSION}

The classification used for the staging of uterine sarcoma is the revised International Federation of Gy- 
necology and Obstetrics (FIGO) 2009 classification for uterine sarcoma. Stage I includes disease limited to the uterus. Stage II includes disease extending beyond the uterus, within the pelvis. Stage III is defined by an abdominal extension of the disease, and stage IV involves direct invasion of the bladder or the rectum, or the presence of distant metastasis (7). Cervical cancer cases in young girls are described in the form of cluster formations that can fill the entire vagina. This is the so-called Botrioid Sarcoma (sarcoma botryoides) (10). Early and complete resection is the best-evidenced treatment for uterine leiomyosarcoma. Oophorectomy and lymphadenectomy may be safely omitted for clinically uterus-confined leiomyosarcoma. Chemotherapy increases survival of women with metastatic leiomyosarcoma (8). Patients suffering from breast cancer, estrogen-dependent, use Tamoxifen in therapy. Tamoxifen is an antiestrogenic drug that is used to prevent or slow down the recurrence of breast cancer after primary therapy, including breast surgery, radiation therapy and chemotherapy. The question is whether the use of Tamoxifen (TAM) increases the risk of developing uterine cancer. Conclusion For most women, the benefits of TAM in preventing a recurrence of $\mathrm{BC}$ outweigh by far the potential risk of uterine cancer. Furthermore, benefit from the TAM has evident survival. In the adjuvant setting, TAM is recommended for a maximum of 5 years (9).

\section{CONCLUSION}

Many questions about sarcomas do not yet have a clear answer, nor do they have clear guidelines for their early diagnosis. It is believed that with uterine sarcomas, due to the conservative possibilities of treatment of uterine myoma with $\mathrm{GnRH}$-analogs and more numerous hysteroscopic procedures, it will be diagnosed more often in the upcoming years.

\section{REFERENCE}

1. F. Amant, E. Steenkiste, K. Schurmans, et al. Immunohistochemical expression of CD10 antigen in uterine adenosarcoma. Int J Gynecol Cancer, 14 (2004), pp. 1118-21.

2. D’Angelo E, Prat J. Pathology of mixed Müllerian tumours. Best Pract Res Clin Obstet Gynaecol. 2011 Dec;25(6):705-18.

3. Chaudhary YS, Illahi F, Moatasim A. Carcinosarcoma uterine unusual histologic presentation. Rawal Med J 2009;34:120-2

4. Kuyumcuoglu U, Kale A. Homologous type malignant mixed Mullerian tumour of the uterus presenting as cervical mass. J Chin Med Assoc 2009;72:533-5

5. Yildirim Y, Inal MM, Sanci M, Yildrim YK, Mit T, Polat $M$, et al. Development of uterine sarcoma after tamoxifen treatment for breast cancer: A report four cases. Int J Gynecol Cancer 2005;15:1239-42

6. Wolfson AH, Wolfson DH, Sittler SY, Breton L, Markoe AM, Schwade JG, et al. A multivariate analysis of clinicopathologic factors for predicting outcome in uterine sarcomas. Gynecol Oncol 1994;52:56-62

7. Philip CA1, Pautier P, Duffaud F, Ray-CoquardI.Highgrade undifferentiated sarcomas of the uterus: diagnosis, outcomes, and new treatment approaches..CurrOncolRep. 2014Oct;16(10):405

8. Seagle BL1, Sobecki-Rausch J2, Strohl AE2, Shilpi A2, Grace A2, Shahabi S2 Prognosis and treatment of uterine leiomyosarcoma: A National Cancer Database study Gynecol Oncol. 2017 Apr;145(1):61-70.

9. Vasconcelos AL1, Nunes B1, Duarte C1, Mendonça V1, Ribeiro J2, Jorge M1, Monteiro Grillo I3 Tamoxifen in breast cancer ipse dixit in uterine malignant mixed Müllerian tumor and sarcoma-A report of 8 cases and review of the literature. Rep Pract Oncol Radiother. 2013 Aug 12;18(5):251-60

10. Katedra za Ginekologiju I akušerstvo, Medicinski fakultet Beograd, Ginekologija I akušerstvo, 2005, Februar, 144-145 